\title{
ELITE CHILDREN IN THE EARLY MIDDLE AGES*
}

\author{
BORZOVÁ, ZuZANA - MOLNÁROVÁ, MARTINA**
}

\begin{abstract}
The paper offers a digression into the issue of a specific group of children in the Early Middle Ages - the children of the elite in the northern region of the Carpathian Basin. By means of analysis and evaluation of the grave goods, the elements of the burial rite of children's graves, it is possible to detect certain distinctive phenomena that show the importance of child individuals of higher social class. In terms of archaeological material, it is shown to a large extent by analogical phenomena of the burials of adult elite individuals. The phenomena manifest themselves with certain deviations due to the effect of a different social and cultural-ethnic development.
\end{abstract}

Keywords: Slovakia, children's graves, social status, elements of the burial rite, grave goods

A tanulmány a korai középkori temetkezések egy különleges csoportját, az elit gyermekeinek sírjait vizsgálja a Kárpát-medence északi térségében. A sírleletek és a temetkezési rítus elemzése és értékelése nyomán felismerhetők bizonyos sajátosságok, amelyek az előkelő származású gyermekek kiemelt helyzetére utalnak, és amelyek többnyire a felnőtt elit temetkezéseit is jellemzik. A gyakorlat bizonyos módosulása figyelhetô" meg eltérö társadalmi és kulturális-etnikai fejlődés hatására.

Kulcsszavak: Szlovákia, gyermeksírok, társadalmi helyzet, temetkezési rítus, sírmellékletek

\section{Introduction}

The period of the Early Middle Ages in Central Europe is characteristic of various ground-breaking changes (ethnic as well as cultural) that demarcate the individual phases of the studied period. Each chronological period of time, in some respects, represents a different historical developmental unit determined by its then society. In

A kézirat beérkezett: 2017. február 27.

* This paper was created within the project VEGA 2/0037/17: "The Role of Material Culture in the Formation of Economic, Social and Interethnic Ties in Medieval Communities".

** Borzová, Zuzana Department of Archaeology, Constantine the Philosopher University in Nitra, Hodžova 1, 94901 Nitra, Slovakia; zborzova@ukf.sk; Molnárová, Martina. A. Hlinku 17/7, 97101 Prievidza, Slovakia; molnarova.mata@gmail. com the archaeological domain, it is expressed by a distinct material culture that, besides other things, also reflects the social class of the said society.

In archaeological culture, the differentiation of the society of that time can be observed according to various domains: material contents, level of architecture, burial rite, etc. It is the analysis of the burial rite (the elements and the grave goods) itself that helps reconstruct the status of mainly the significant, highly ranked individuals in a given society, to which we can assign the youngest ones - children.

The source base to the given topic is chiefly comprised of children's graves from the $6^{\text {th }}-12^{\text {th }}$ century from the territory of Slovakia. Out of all the sources published so far, we identify 3,469 children's graves of all age groups from 143 early 
medieval sites on Slovak territory. However, the initial source base 'only' covers the age group categories infans I and infans II ( $0-14$ years) that represent 2,661 individuals from 134 early medieval sites. ${ }^{1}$ By means of analysis of these children's graves, it is possible to observe some of the elements of the burial rite as well as the grave goods with the aim to discern the elite status of children in the Early Medieval society.

In this context it is important to point out the essentiality of interdisciplinary collaboration when dealing with the stated issue. When evaluating children's burials on our territory, it is only possible to proceed from the results of anthropological analyses - the age and gender of these children. The number of these analyses, however, is still not sufficient, even though there has been an increase in the amount of paleopathological analyses in the recent years. ${ }^{2}$

In the context of the Early Middle Ages, the evaluation of this specific phenomenon, apart from natural scientific evidence, also requires evidence of historical and iconographical nature; despite the fact that the latter did not bring any satisfactory nor relevant findings from our territory. Ethnographic parallels could also be a contribution; however, their results should only be interpreted with a large amount of caution. Considering all the possibilities for research of the given topic on the territory of Slovakia, or rather of the territory of Central Europe, archaeology decidedly remains the primary source of information.

\section{Elite children and their status in the individual stages of the Early Middle Ages}

A characteristic feature of the beginning of the Early Middle Ages (late $5^{\text {th }}$ century to mid- $7^{\text {th }}$ century) were crematory burials with poor crematory urn and pit graves, ${ }^{3}$ on the grounds of which it is not possible to observe the level of social differentiation and thus detect the elite status of children in the society.

\section{Mid-7 $7^{\text {th }}$ century to early $9^{\text {th }}$ century}

We can observe a completely different situation in the period of the Avar Khaganate (mid-7th cen-

1 This database is a part of the diploma thesis, which has been written in the Department of Archaeology at the Faculty of Arts of Constantine the Philosopher University in Nitra: Molnárová 2015.

2 E.g. BEŇUŠ et al. 2006; BEŇUŠ et al. 2007; BEŇUŠ et al. 2010; DÖRNHÖFEROVÁ-BEŇUŠ 2010.

3 FUSEK 1994, 151. tury to early $9^{\text {th }}$ century). During this phase of the Early Middle Ages, the southern part of Western, Central and Eastern Slovakia comprised the so-called northern periphery of a governmental and political structure - the Avar Khaganate. ${ }^{4}$ In this very area we can detect the occurrence of biritual cemeteries, typical for the presence of crematory and inhumation graves. Inhumation graves provide valuable information about the life of the local society. One of them is social differentiation that, in case of inhumation graves, can be manifested in several different ways ranging from special modifications of the grave to rich grave goods.

It is possible to identify an extraordinarily distinctive group of child individuals from this period, whose burial rite and grave goods strikingly

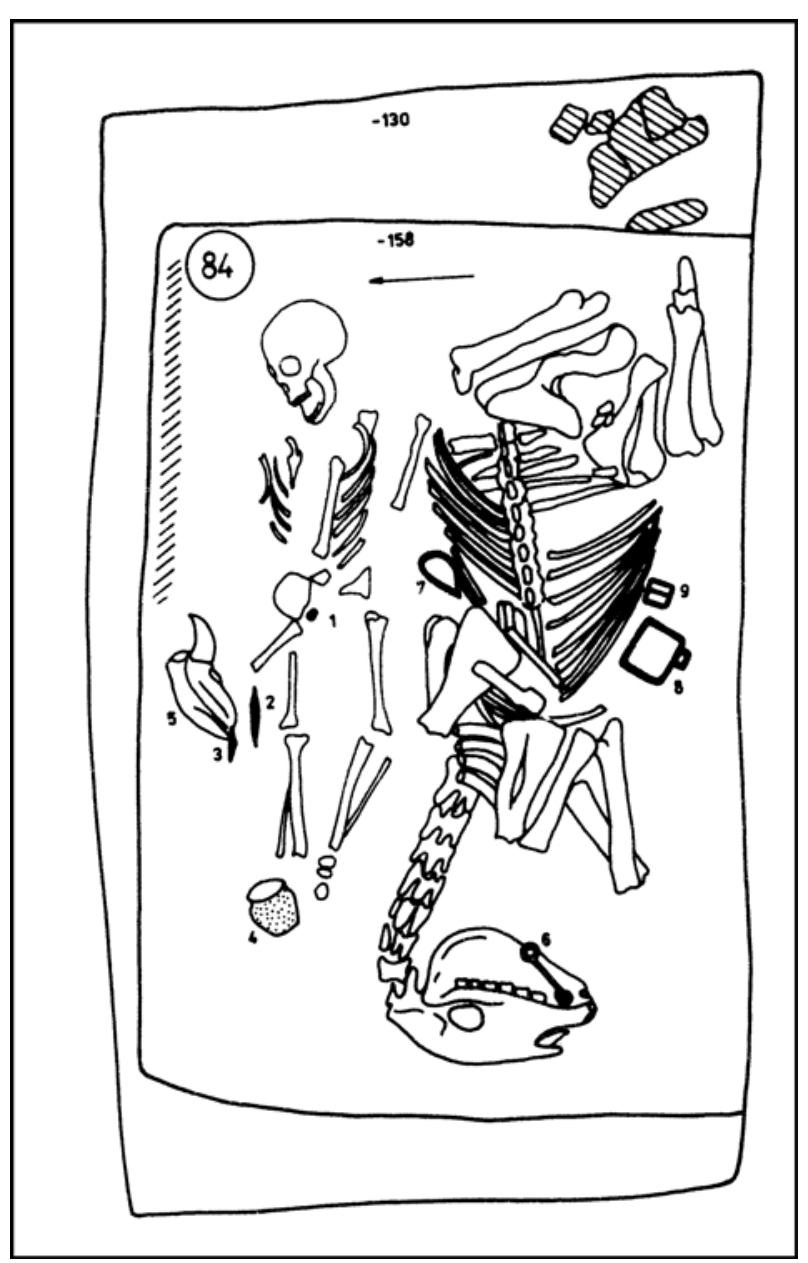

Fig. 1. Košice-Šebastovce. Children's 'cavalry' grave no. 84 with a horse buried in the opposite orientation (after BUDINSKÝ-KRIČKA-TOČík 1991, 105, Fig. 7).

1. kép. Kassa-Zsebes/Kosice-Šebastovce, 84. sír. Gyermek "lovas” és ellentett tájolású ló (BUDINSKÝ-KRIČKA-ToČík 1991, 105, Fig. 7 nyomán)

4 Zа́војNík 2004, 24, Fig. 2. 


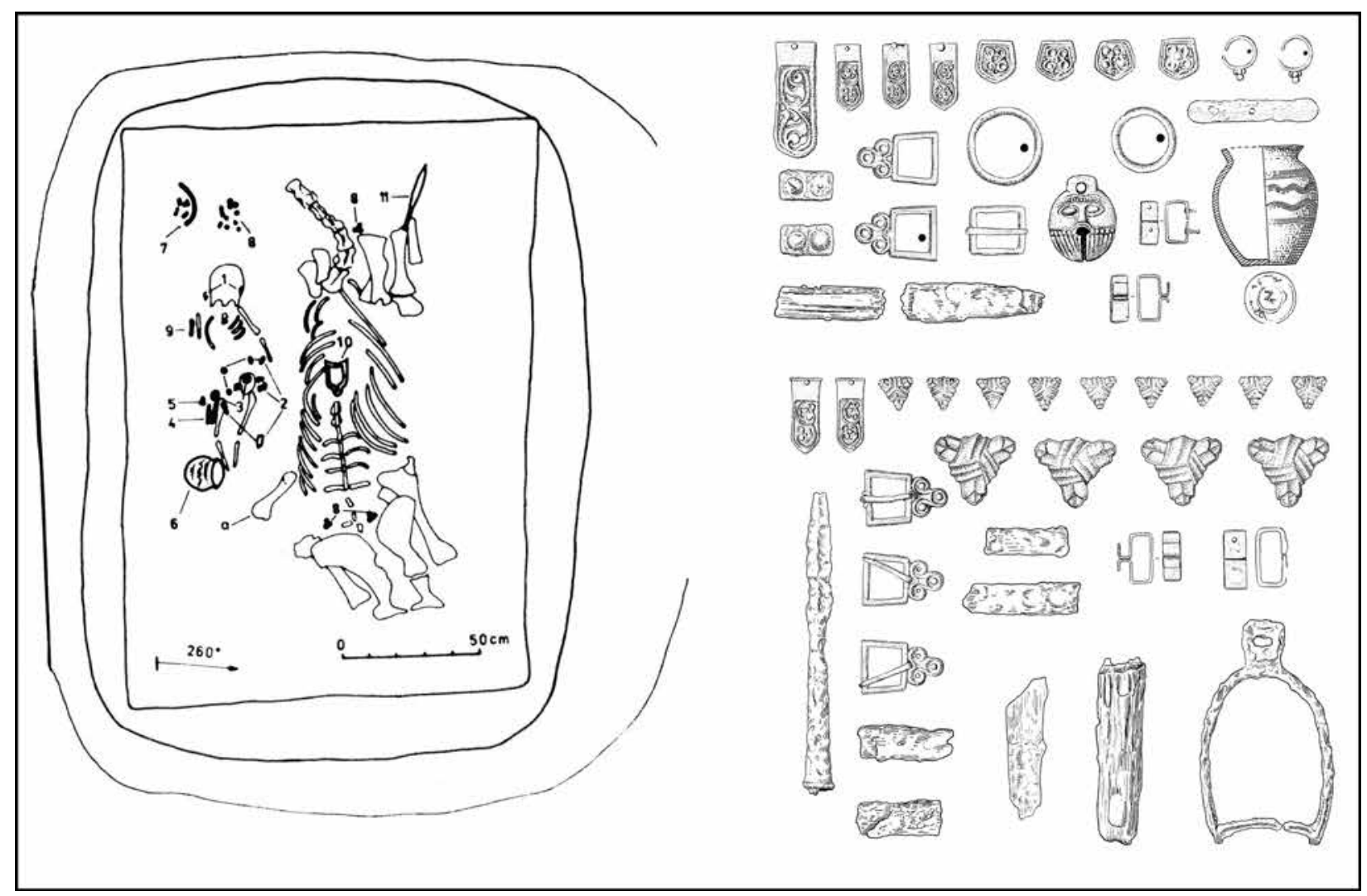

Fig. 2. Komárno-Varádiho Street. Child grave no. 11, with the presence of weapons, a sleigh bell and rich grave goods (after ČILINSKÁ 1982, 350, Fig. 1:5; 376, Tab. IV: 21-43; V: 1-27, modified).

2. kép. Komárom/Komárno-Varádi utca. 11. sír fegyverekkel, csengővel és gazdag sírmelléklettel (ČILINSKÁ 1982, 350, Fig. 1: 5; 376, Tab. IV: 21-43; V: 1-27, módosítva)

resemble a certain significant class of the adults of the Avar society - the cavalrymen, typical members of the Avar military force. Cavalry graves are not only distinguished by the presence of the attributes of the horseman himself. The skeletal remains of the horse are present as well. ${ }^{5}$ The same applies to the children 'cavalry' graves. Meaning that a child accompanied by wealthy grave goods was buried alongside a horse with opulent saddlery.

There are all in all 18 registered children 'cavalry' graves from six cemeteries on the territory of Slovakia from the period of the Avar Khaganate. ${ }^{6}$ They are located within the corresponding burial ground between the graves of adult horsemen or between the regular ones without any visible accumulation. Based on the anthropological analysis, it is possible to determine that the bodies belonged to boys, primarily of the infans II age group (7-14 years) and, in isolated cases, infans I (up to 6 years). The body of

5 ZÁBOJNÍK 2004, 35.

6 Molnárová 2015, 93. the horse, in the vast majority of these children's graves $(68 \%)$, is placed at the right-hand side of the 'horseman' in the same direction as the child's body and a NW-SE grave orientation, similar to the adult horsemen. ${ }^{7}$ Other children 'cavalry' graves, all from the Košice-Šebastovce burial site, ${ }^{8}$ are E-W oriented with the body of the horse positioned in the opposite direction to the human body (Fig. 1).

Child individuals, similar to the adult cavalrymen, are sent to the other side equipped with an abundance of grave goods, which, in case of the adult individuals, serves as evidence of their social rank. ${ }^{9}$ Grave goods of children are equally pompous and often include weaponry (spearheads, arrowheads, daggers, parts of bows, sabres, etc.), alloy parts of belt sets and horse harnesses as well as splendid jewels. ${ }^{10}$

There is an interesting observation in connection with grave goods in these children's graves:

\footnotetext{
7 ZÁвOJNíK 2004, 35.

8 BUDINSKÝ-KRIČKA-TOČÍK 1991.

9 ZÁBOjNÍK 1995, 264; 2004, 41.

10 Molnárová 2015, 95, Fig. 10.
} 
there are multiple cases of younger children (infans I and II), whose graves are much more richly equipped than the graves of older ones (juvenis). This speaks in favour of the surmise that the given objects do not serve a practical purpose, but rather a symbolical one, to point out the high social status of the child in the society. ${ }^{11}$

A classic example is represented by two children's cavalry graves from this site with the richest grave goods, both belonging to individuals of the anthropological age estimation infans I, ranging from 1-3 years of age. ${ }^{12}$ These children are simultaneously the youngest separately buried children in cavalry graves. The first grave, grave no. 109 , is situated on the cemetery in KomárnoLodenica II. A six-year-old boy was buried with gold-plated bronze belt parts, a gold-plated decorated bronze phalera and a bucket handle fitting. ${ }^{13}$ The second grave, no. 11, from KomárnoVarádiho Street, ${ }^{14}$ is of a three-year-old boy. The child was buried alongside two weapons: a spear and a dagger. The grave goods further consisted of belt parts represented by several gold-plated and bronze fittings and ferrules. Apart from these warrior-like attributes, this child horseman was equipped with a pair of golden grape earrings in a functional position on both sides of the skull, as well as a sleigh bell (Fig. 2). ${ }^{15}$

We encounter another very specific group of children's graves on the contemporary cemeteries that originated during the period of the Avar Khaganate - richly equipped children's graves without the presence of a horse. These children's graves are characterized by wealthy grave goods, similar to those of the elite adult individuals of the then society, which means that grave goods are indicative of their social status.

An example of this is a child grave no. 119 from a cemetery in Čataj, where a child was buried with a set of bronze belt fittings (Fig. 3), the remains of a glorious belt, which was a component of a traditional costume for men and symbolized power, wealth and social rank of the bearer. ${ }^{16}$ Another case from the mentioned cemetery, a child grave no. 170, displays a child equipped with various weapons that, in adult male graves, symbolize a warrior (Fig. 4). A specific example is the child grave no. 151 from the Čataj cemetery. Besides other things, this grave includes a weapon - a seax, the symbol of a male

\footnotetext{
11 BRATHER 2004, 159-160; MOLNÁROVÁ-BORZOVÁ 2016, 61-63.

12 JAKAB 1993, 311; JAKAB-VONDRÁKOVÁ 1982, 398.

13 Trugly 1993, 198, 254, Tab. XVII: 1-13.

14 ČILINSKÁ 1982, 349.

5 ČILINSKÁ ibid.

16 ZÁBOJNÍK 2002, 39.
}

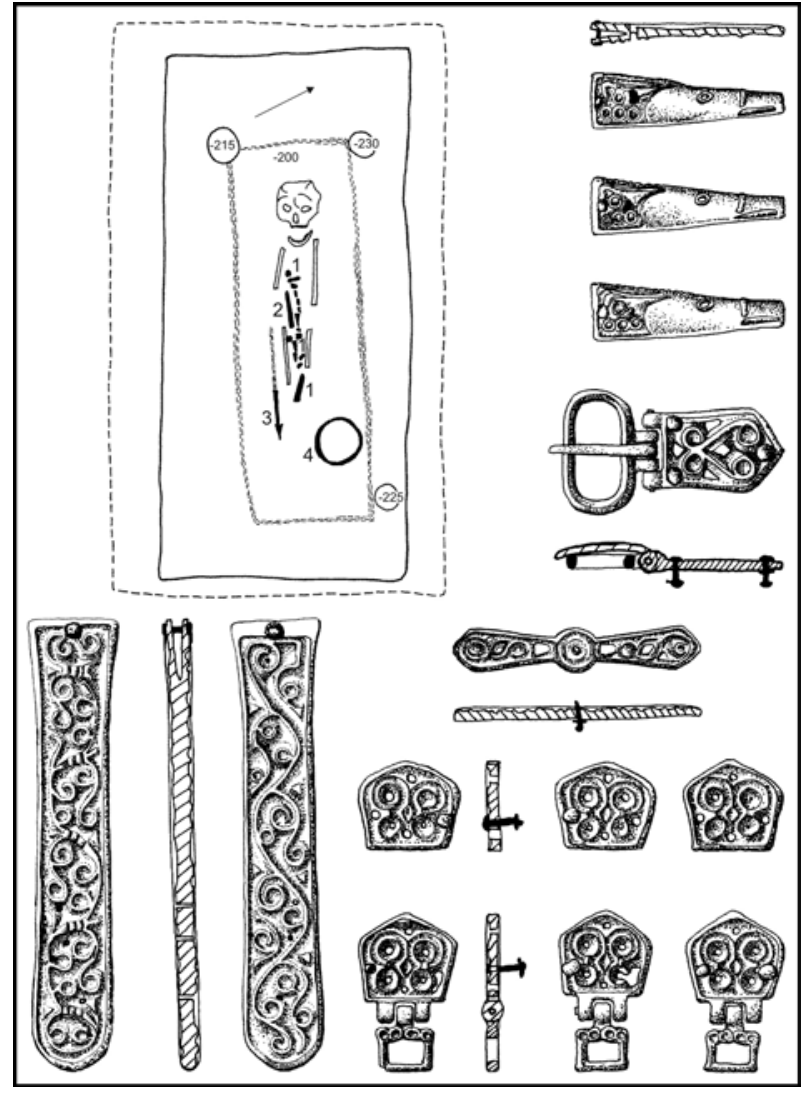

Fig. 3. Čataj. Rich child grave no. 119 (after ZÁBOJNík 2015, 282, Fig. 2, modified)

3. kép. Csataj/Čataj. 119. sír (ZÁвOJNík 2015, 282, Fig. 2 nyomán, módosítva)

warrior. What is remarkable about this grave is the fact that this child, apart from the weapon, was equipped with a pearl necklace - a typical female jewellery - located in a functional position, on the neck (Fig. 5), similar to some of the above-mentioned children's 'cavalry' graves. A similar situation, when a child's grave includes both typically male attributes together with bounteous jewellery that can be associated exclusively with females, can be observed on the grounds of the Želovce cemetery. A sabre and a belt plate set from grave no. 490 can be considered a typically male, warrior-like attribute, indicative of power. However, the grave contained a typically female piece of jewellery - silver earrings located at both sides of the skull. ${ }^{17}$

Female jewellery, especially earrings or temple rings make up the fundamental part of grave goods in case of elite adult female individuals. Similarly, grave goods from girls' graves mostly consisted of various kinds of jewellery, especially of earrings and necklaces, as well as of articles of

17 ČILINSKÁ 1973, 123-124. 


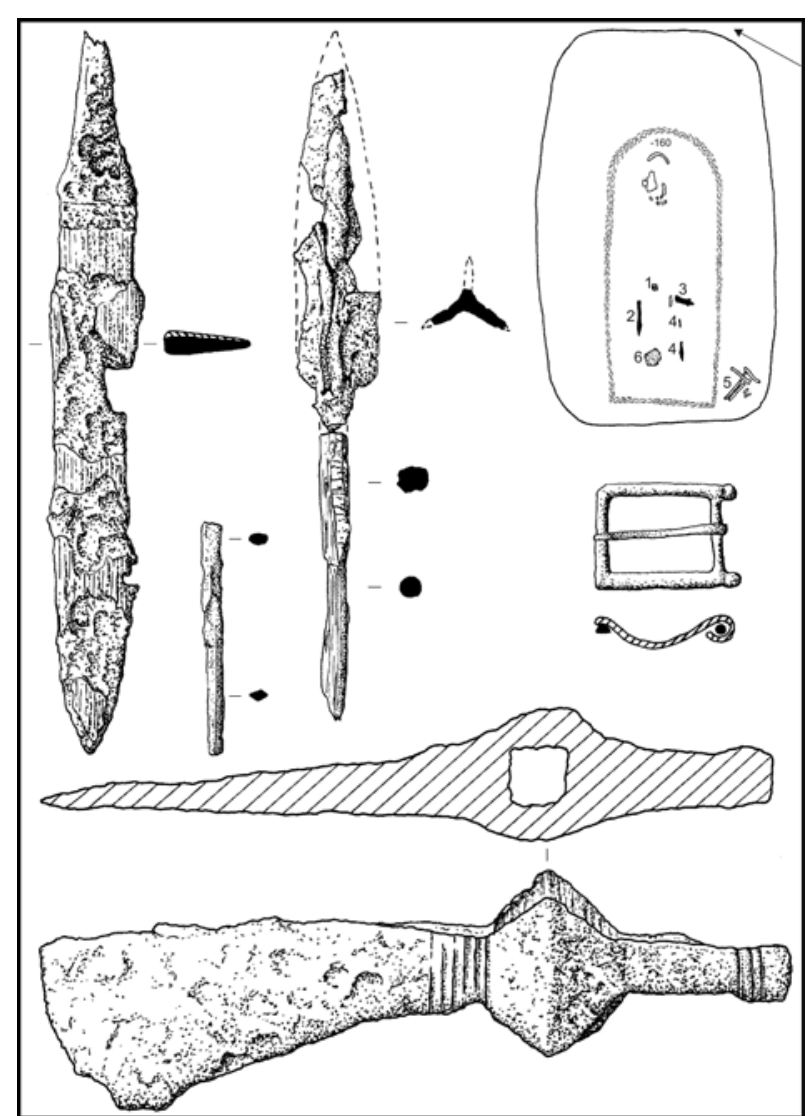

Fig. 4. Čataj. Child grave no. 170 equipped with weapons (after ZÁвOjNíK 2015, 197, Fig. 1)

4. kép. Csataj/Čataj. 170. sír, fegyvermellékletekkel (ZÁBOJNíK 2015, 197, Fig. 1 nyomán)

daily use, represented by a spindle whorl and in isolated cases a needle case and needles.

Apart from grave goods, close attention was paid to modifications of the burial pit - especially by means of wood. One of such wealthy graves with timbering is the grave no. 245 from Nové Zámky of a girl buried with a pair of bronze earrings, beads, a spindle whorl with a pot, three bronze bracelets and a bronze ring. ${ }^{18}$ Some cavalry graves and wealthy graves of young males were made up in a similar manner.

The same aspects, proving high social status of a buried child, can as well be found in the context of children's double graves. In this case, children were sent to the other side equipped with a fair amount of additional items of high economic value. One of such graves worth mentioning is a very wealthy children's double grave no. 231 from Košice-Šebastovce. ${ }^{19}$ There were two children buried in it, one of the age category infans I

18 ČILINSKÁ 1966, 51.

19 BUDINSKÝ-KRIČKA-TOČíK 1991, 49-50.

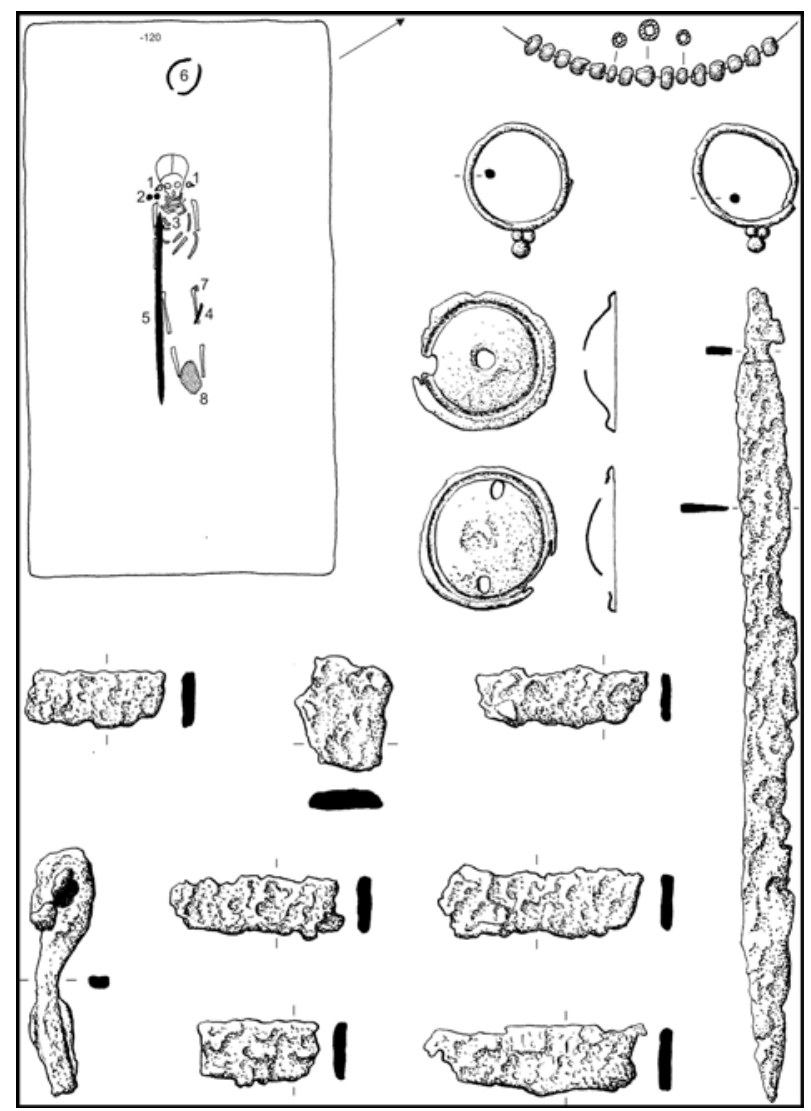

Fig. 5. Čataj. Combination of female and male status objects present in the child grave no. 151 (after ZÁвOJNík 2015, 284, Fig. 4)

5. kép. Csataj/Čataj. 151. sír előkelő férfi- és női mellékletekkel (ZÁBOjNík 2015, 284, Fig. 4 nyomán)

(5-6 years old) and the other one of the infans II category (8 years old). The elder was buried with an iron hatchet located next to its head. In the waist area there were parts of a belt set and a round bronze sleigh bell. Two arrow heads were placed next to the right shin of the child. The grave goods of the second, younger child included two twisted bar bronze torcs, a couple of beads, a bronze earring, an iron knife and a buckle as well as a pot. ${ }^{20}$ Other similarly equipped children's double graves are the double grave no. 121a from Radvaň nad Dunajom ${ }^{21}$ and the children's double grave no. 315 from Želovce. ${ }^{22}$

Within the context of joint graves, it is necessary to mention another significant group of children from the Avar Khaganate society. These children were put in the grave without any grave goods but were for some reason buried with elite adult individuals - the cavalrymen. This phenomenon occurs several times within the studied

\footnotetext{
20 BudinSKÝ-KRIČKA-ToČíK 1991, 162, Tab. XXXII: 418.

21 ТоС̆́́K 1992, 52.

22 ČILINSKÁ 1973, 92.
} 


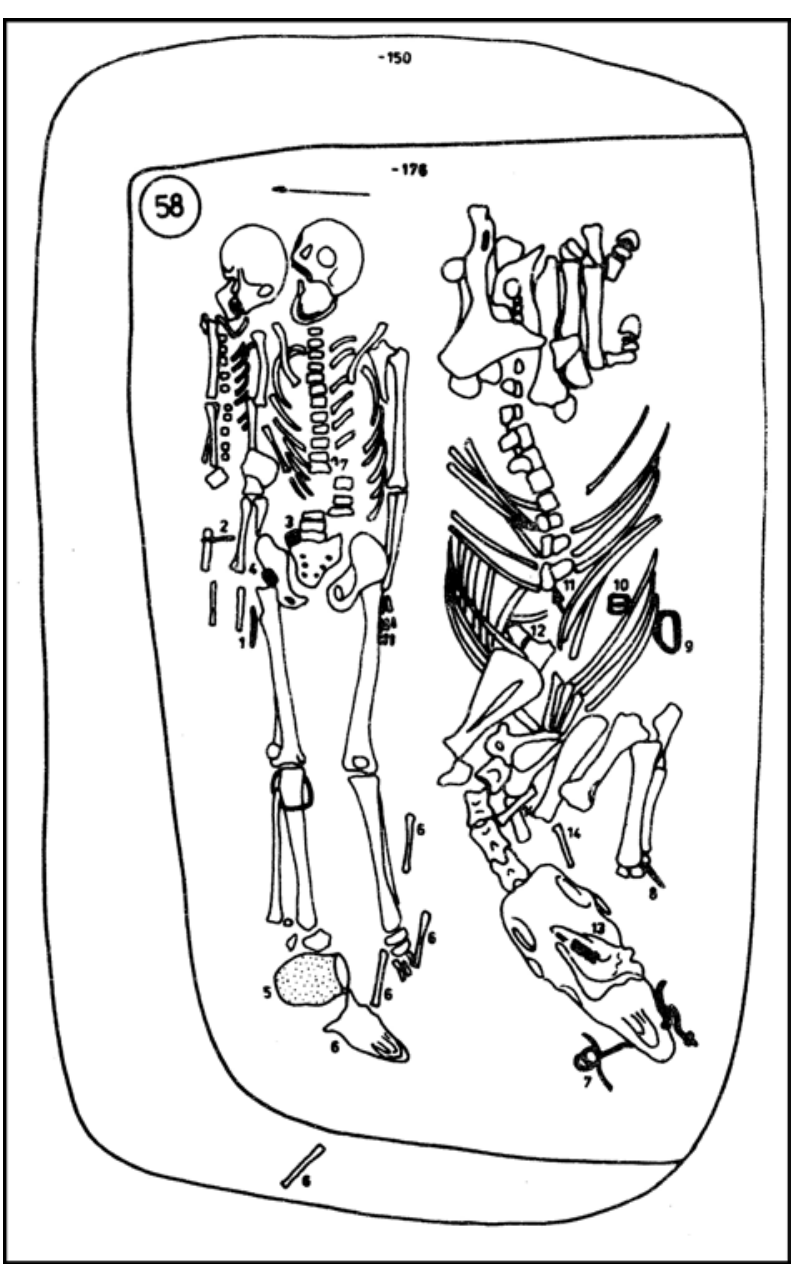

Fig. 6. Košice-Šebastovce. Joint burial of a child and an elite adult horseman in a cavalry grave no. 58 (after BUDINSKÝKRIČKA-TOČíK 1991, Fig. 4)

6. kép. Kassa-Zsebes/Košice-Šebastovce. 58. sír. Felnőtt lovas és gyermek kettős temetkezése (BUDINSKÝ-KRIČKA-TočíK 1991, Fig. 4 nyomán)

sample. One of the cases is the cavalry grave no. 58 from the Šebastovce cemetery (Fig. 6). Alongside the cavalryman a six-year-old child was buried, placed at the right-hand side of the adult. ${ }^{23}$ A similar situation is documented by a triple grave no. 22 from a necropolis in KomárnoHadovce, in which a horseman with wealthy grave goods was buried. One child was placed on his chest; another child's skull was located next to his right leg, also with no grave goods. ${ }^{24}$ Another child was buried under similar circumstances next to a horseman on the Štúrovo cemetery, on the location of Vojenské cvičisko. The grave showed traces of wooden lining, on which the child's body was rested and buried original-

23 BUDINSKÝ-KRIČKA-TOČíK 1991, 17.

24 ČILINSKÁ 1982, 360, 361, Fig. 4:9. ly. ${ }^{25}$ Grave no. 1 from the site of Žitavská Tôn̆ represents a strange situation, when alongside of two cavalrymen a newborn was buried as well. ${ }^{26}$

Except for the stated joint cavalry graves, there are graves from the period of the Avar Khaganate that had different contents. An adult individual was buried in them with rich grave goods, together with a child. In most cases there were special modifications made to the burial pit, except there was no horse. In these cases, the rich grave goods relate to the adult, too and the child is placed into the double grave without any personal effects. One mentionable case of male graves is the grave no. 744 from the cemetery in Holiare. An adult male was buried with wealthy grave goods that reflect his social rank. A small child was placed on his chest in an embrace. ${ }^{27}$ Another warrior from the grave no. 124 from Želovce was buried in a specially modified grave of large dimensions together with a child of 8-9 years of age. The child was placed next to the warrior's right leg in an opposite orientation. ${ }^{28}$ In the grave no. 117 on the cemetery in Prša, a man was buried with a child in a large burial pit with special wooden modification. The man, apart from the ordinary everyday items, was equipped with a rich bronze belt set. ${ }^{29}$ Other similar, yet female graves of fortune with the presence of a child are for example the two double graves from Želovce. ${ }^{30}$

The reason behind the aforementioned burials of children put into graves together with an elite member of the Avar society has not been clarified yet. ${ }^{31}$ We can consider the possibility that the cavalryman and the child were somehow related. In that case, the burial of the child would signify its social status or, to be precise, its affiliation with the elite (cavalry or military) class of the society. Our second hypothesis is based on ethnographic parallels from the territory of Africa, where double graves of adult males buried with newborns occur as well. These men are elite members or other significant representatives of a certain community that expresses their social rank in this manner. The mission of a newborn child buried alongside a man was to ensure a safe passage to the other side and guarantee a peaceful afterlife of the deceased man. ${ }^{32}$ With this hypothesis, we

25 Tơ̌ík 1968b, 16-17.

26 ČILINSKÁ 1963, 87.

27 Točík 1968a, 113-114, Fig. 35.

28 ČILINSKÁ 1973, 57.

29 Тос̌і́к 1963, 146-147.

30 No. 24 and no. 396; ČILINSKÁ 1973, 37-38.

31 TOMKA 2003.

32 E.g. Crawford 2007, 90; ČllinsKá-WolsKa 1979, 148; D̃uricová 2012, 135. 
can also speculate about the exceptionality of the child that was supposed to fulfil such an important task. Whether it was a child from the elite class or not, remains uncertain.

\section{Mid-9 th to early $10^{\text {th }}$ century}

In the following decades, the so called Great Moravian Period comes the time of changes in power and politics, as well as cultural, spiritual and ideological changes. These reflect in the burial rite, thanks to which we can observe the exceptional status of some children of the then society. On inhumation cemeteries, we find graves with rich, splendid grave goods. Their contents usually served as symbols of high social status: armour and parts of horse riding equipment, various jewellery pieces, parts of clothing and belt fittings. ${ }^{33}$

Armour and horse riding equipment (especially spurs) express social status of an elite class of the society - the warriors. Apart from adult graves, these objects are also found in children's graves. Spurs are one of them. In comparison to neighbouring territories, where spurs were nothing unusual in the context of elite children's graves, ${ }^{34}$ their occurrence in our area is rather rare. To give an example, we can mention a unique grave from Kamenín, location Kiskukoricás. In this grave, alongside an adult male a small child was buried (younger than 2 years of age), equipped with two spurs, an axe and pots. ${ }^{35} \mathrm{~A}$ boy from the cemetery in Bojničky also had a spur placed between his feet. In addition to the spur, there was an iron knife, two strap ends and two harness buckles (Fig. 7). ${ }^{36}$

When expressing higher social status in the monitored period, we can see another more common phenomenon - placement of weapons into children's graves. In our area we can only speak of axes and these are of the same size as the ones found in adult warrior graves from the Great Moravian Period. In almost all cases, weapons were accompanied by a knife or items of daily use such as fire strikers and flint. Despite the fact that the aforementioned warrior attributes are placed in a functional position, they 'only' hold a symbolic function. Their task is to epitomize the child's status, analogous to their task during the period of the Avar Khaganate.

The social status of children during the observed period is often also demonstrated by jew-

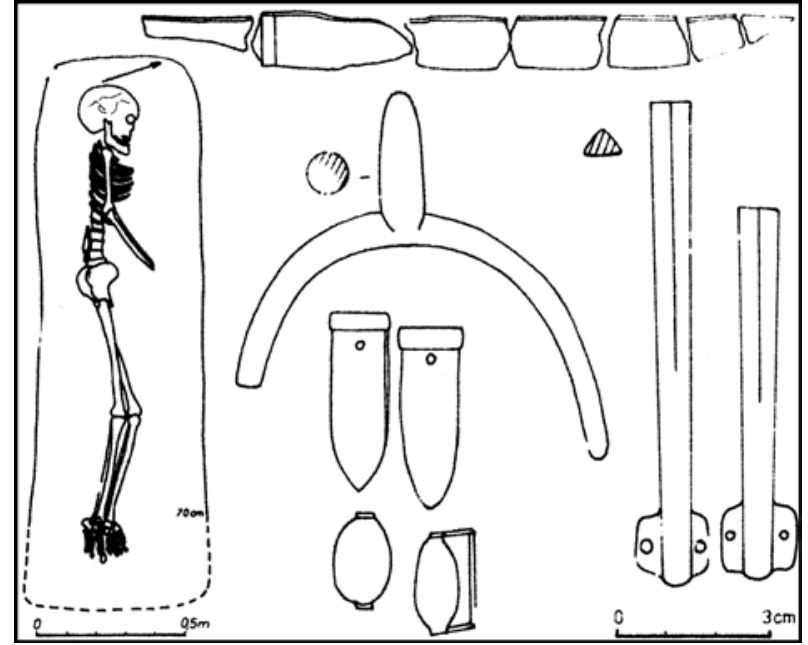

Fig. 7. Bojničky. Boy with grave goods symbolizing cavalry attributes (after BIALEKOVÁ 1993, Fig. 8:5, modified)

7. kép. Bajmócska/Bojničky. Gyermek jelképes lovas temetkezése (BiALEKOVÁ 1993, Fig. 8:5, módosítva)

ellery, clothing accessories (especially pompous buttons) and belt fittings. Jewellery in children's graves from the $9^{\text {th }}$ century is extremely rich in all the different types and shapes; in some cases they have a strong quantitative representation. Based on the present results of anthropological analyses, we can assume that jewellery, in varying quantitative and qualitative proportions, was put primarily into graves of young females of all age groups. A prime example is the grave no. 123 from the cemetery in Čakajovce, where a child was buried with an enormous amount of female jewellery (Fig. 8). ${ }^{37}$

Elite status of children of the period in question is not only documented by rich grave goods but by a specific burial rite as well. On plane burial grounds, it is manifested by a specific modification of the grave. An example of this is a wooden coffin carved out of a single piece of wood from a girl's grave located on the cemetery in Blatné, which also contained rich grave goods. ${ }^{38}$

It is possible to observe manifestations of social differentiation in this period thanks to tumuli, not only by the contents of the inventory but especially by the spatial distribution of graves and their burial rite. A unique example of this kind is a grave of a boy from the tumulus no. 12 located on a cemetery in Skalica. ${ }^{39} \mathrm{He}$ was buried in a grave underneath a raised burial mound, in like manner of adult warriors from the same

\footnotetext{
37 RejHOLCOVÁ 1995, 13-14.

38 KRASKOVSKÁ 1966, 99.

39 BUDINSKÝ-KRIČKA 1959,12.
}

\footnotetext{
33 HANULIAK 2004; 2010.

34 E.g. Profantová 2005, 75.

35 NEVIZÁNSKY 1980, 187-188.

36 BialeKová 1993, 226-227.
} 
cemetery, in a wide burial pit with his head propped up with an oak plate strewed with moss. The boy was equipped with a knife, an axe and two stirrups. Apart from the mentioned grave, there are other, richly equipped children's graves located in this necropolis. Next to their wealthy grave goods and the inner modification of the burial pit, they are characteristic of their special position within the cemetery - nearly all of them were unearthed in the southwestern part of the tumulus. ${ }^{40}$ The manifestation of higher social status of children in the Great Moravian Period can be further demonstrated on a specific grouping of graves of children buried together with adults. In these discovery sites with wealthy grave goods, the child is usually buried alongside an adult with elite status. In these cases the high social rank of a child in the then society is expressed by the presence of an adult elite individual, as well as the bounteous grave goods in the child's possession. In some instances the ex-

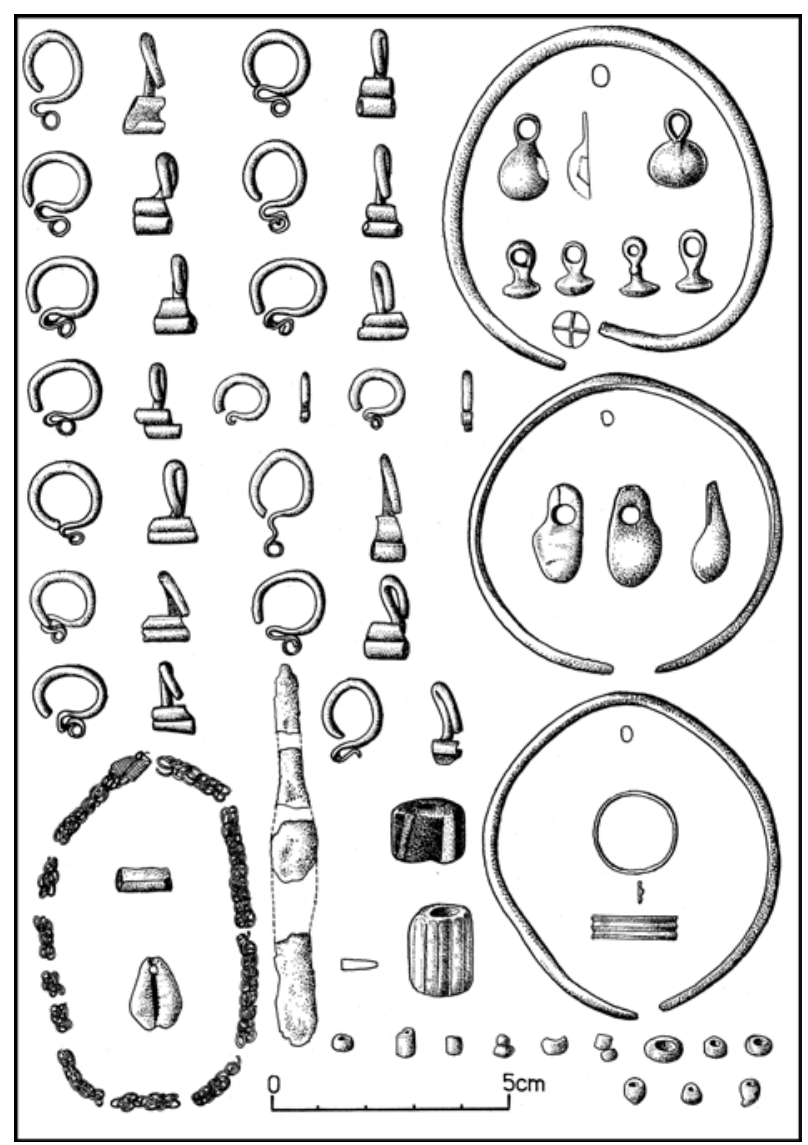

Fig. 8. Čakajovce. Grave no. 123 of a girl with a large amount of female jewellery (after REJHOLCOVÁ 1995, 118, Tab. XXVIII)

8. kép. Csekej/Čakajovce. 123. gyermeksír női ékszerekkel (RejHOLCOVÁ 1995, 118, Tab. XXVIII nyomán) ceptional social status is amplified by special modification of the grave. For example, the grave no. 166/85 from Devín-Za kostolom holds the body of an adult female with skeletal remains of a newborn child on her chest (Fig. 9). The construction of the grave alone shows indications associated with higher social status. There is evidence of timbering and even stones located above the deceased female, presumably for the purpose of grave lining. The 30-year-old had wealthy grave goods and the two spherical iron rattles with a vertical ridge around its circumference belonged to the child. There was a silver earring on each side of the woman's skull, a fragment of a ring was found on the left side next to one of the earrings, a necklace was placed underneath the lower jaw. There was also a spindle whorl next to her pelvis and a knife near the left hand. ${ }^{41}$

Apart from the aforementioned group, there are other kinds of double graves - ones with an

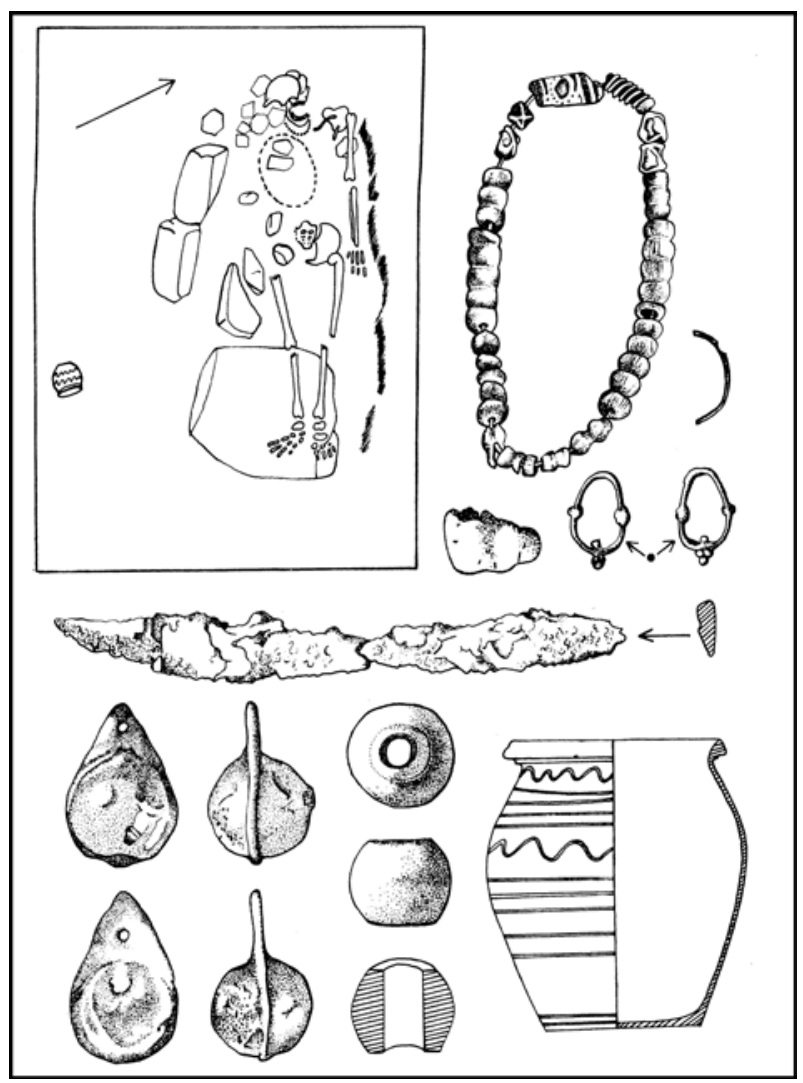

Fig. 9. Devín-Za kostolom. Grave no. 166/85 of a woman and a newborn child with rich grave goods from the cemetery (after PlACHÁ et al. 1990, 103, modified)

9. kép. Dévény-Za kostolom/Devín. Nő és újszülött sírja (166/85) gazdag sirmellékletekkel (PLACHÁ et al. 1990, 103 nyomán, módosítva) 


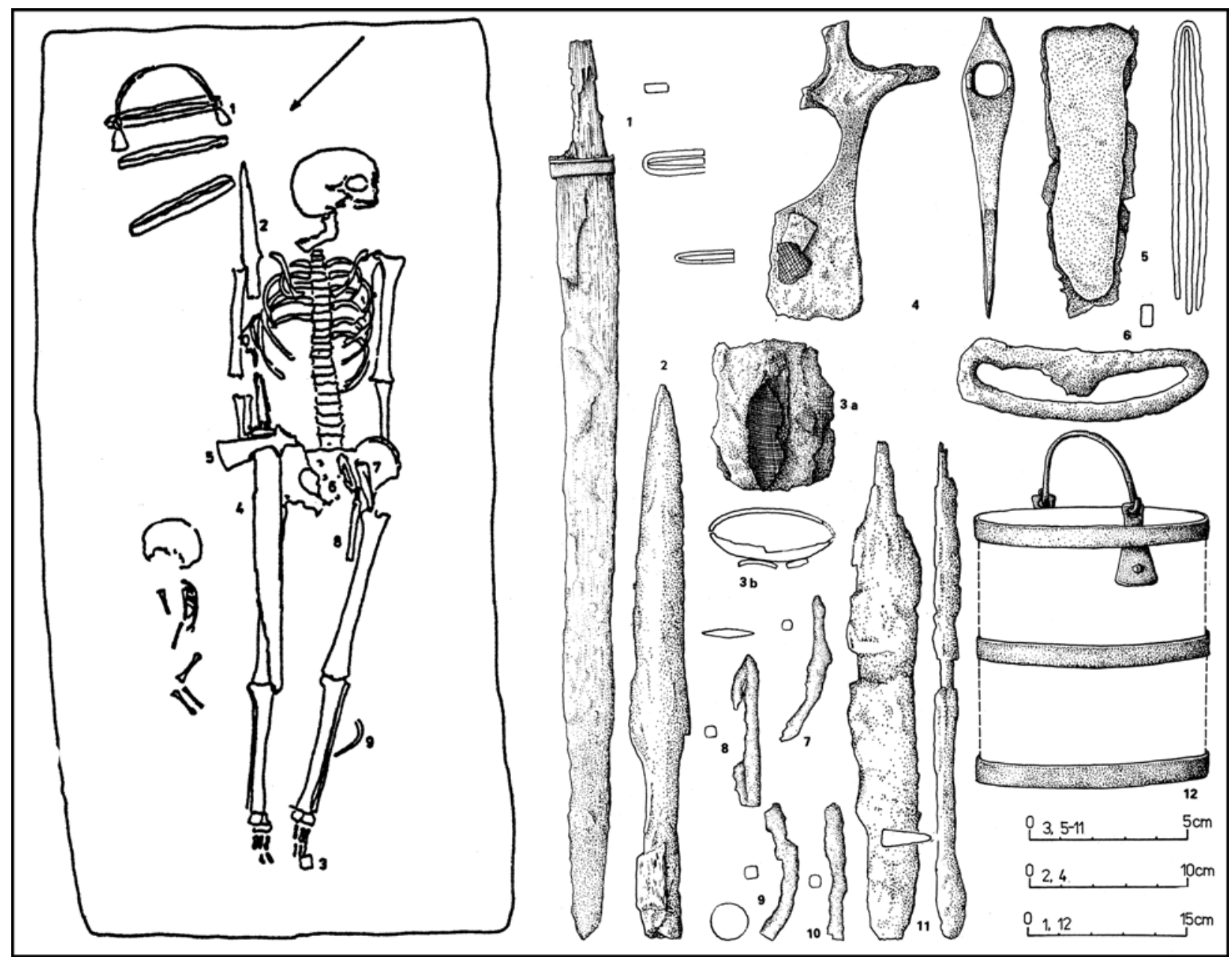

Fig. 10. Čakajovce. Double grave no. 587: a man with rich grave goods and a child without grave goods from the cemetery (after RejHOlCOVÁ 1995, Tab. XCIV; CXL:5, modified).

10. kép. Csekej/Čakajovce. Kettős temetkezés (587. sír): gazdag mellékletú férfi és melléklet nélküli gyermek (REjHOLCOVÁ 1995, Tab. XCIV; CXL:5 nyomán, módosítva)

adult elite member (with typical attributes) buried with a child with no grave goods. One such grave is the double grave no. 587 from the cemetery in Čakajovce, where a warrior was buried with a child of only 6 months of age positioned next to his leg in a moderately flexed position. The adult was equipped with an array of weapons (a spear, a seax and an axe) and items of daily use (a fire striker, a razor and a knife in a leather pouch), unlike the child, which was buried with no grave goods whatsoever (Fig. 10). ${ }^{42}$ A similar situation from the same burial site can be observed on the double grave no. 154, where a woman was buried together with a child of the infans II age category. While the woman was sent to the other side with three temple rings and a ring, there were no findings of the child's

42 RejHOLCOVÁ 1995, 184. possession. ${ }^{43}$ In these cases, as well as in similar cases from the previous period (the Avar Khaganate), we can speculate about a child's higher rank, even though its social status remains unknown. ${ }^{44}$

Another particularity in terms of burial rite that has to do with the adoption of Christianity in Central Europe are churchyard burials. High representatives of the contemporary communities were buried as close to the sacred building as possible as a symbol of their social status. Despite the fact that we do not come across similar cases of elite children buried in immediate vicinity of a sacred building, it is not an uncommon sight in the territory of Central Europe. Instances can be found in the neighbouring Czech Republic and Moravia. As evidence serve the graves from an

43 RejHolcová 1995, 17-18.

44 E.g. CRAWFord 1993, 89. 


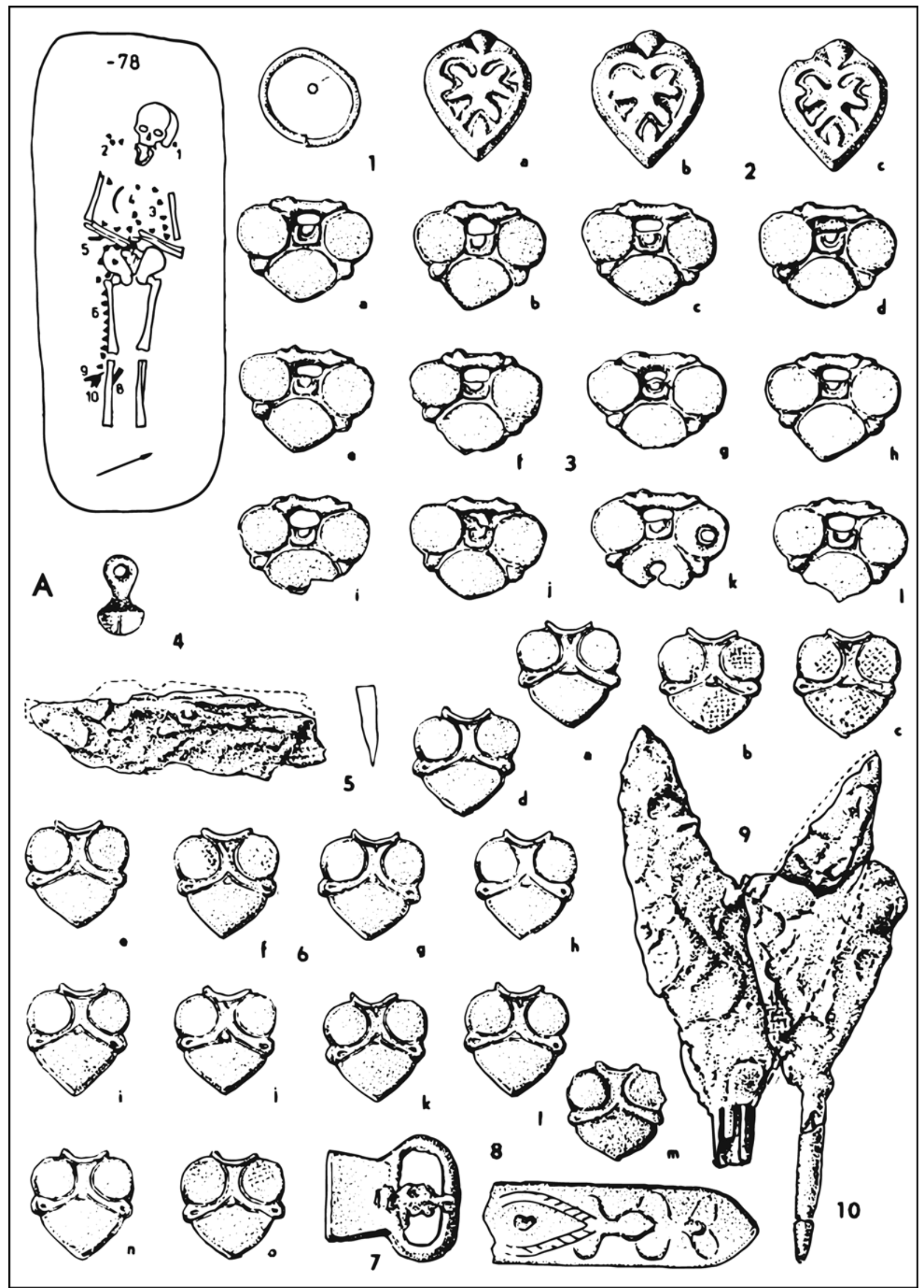

Fig. 11. Malé Kosihy. Grave no. 261 of palatial child with rich grave goods (after HanULiaK 1994, 129, 192, modified) 11. kép. Kiskeszi/Malé Kosihy. 261. sír. Fejedelmi gyermek gazdag sírmellékletekkel (HANULiAK 1994, 129, 192 nyomán) 
expansive centre of power in Mikulčice, where child individuals with rich grave goods were buried in necropolises at close quarters of several churches. The location of the grave (in this case as close to the sacred building as possible), the size of the grave and modification of the burial pit by means of wood can also be considered other dominant features of social status in this period, apart from grave goods. In this context there are all in all eight children burials within the sacred complex located in Uherské HradišteSady, two of which (22/59 and 166/59) also contained spurs. ${ }^{45}$ The same attributes can be found in other necropolises of that time in the complexes of centres of power with the presence of a sacred building. Some of them are: the grave no. 70 near the Church VI in Mikulčice ${ }^{46}$ or the grave no. 24/86 of a boy from the cemetery $U$ rotundy sv. Petra, located in the Czech Budeč. ${ }^{47}$

\section{$10^{\text {th }}$ century}

Even after the arrival of the new ethnic group to the Carpathian Basin - the Magyars - we can still find rich children's graves. It is largely quantitative representation, numbering one to two children's graves at the most, out of the total number of graves within the entire amount of graves in the specific necropolises. Extraordinary social status of children is manifested especially by the presence of opulent jewellery and parts of clothing in these children's graves.

In case of grave no. 5 from the Mužla-Čenkov necropolis, location Orechový sad, that dates back to the $10^{\text {th }}$ century, the child was buried with two silver gold-plated buttons decorated with damascening inlays. ${ }^{48}$ A very typical jewel found in children's graves of this period are heart-shaped pendants, found e.g. in grave no. 14 on the burial grounds of Dubník, location Bundás from the $10^{\text {th }}$ century..$^{49}$ Other component parts of splendid children's graves were s-shaped temple rings, numbering about 10 and more, found e.g. within the burial site of Nitra, location Pod Zoborom in children's graves nos. 37, 81, 100 and $151 .{ }^{50}$

However, the largest amount of elite-equipped child individuals can be found on the burial grounds of Malé Kosihy, location Horné Konop-

\footnotetext{
45 GaluŠKa 1996, 89, Fig. 16; Profantová 2005, 76.

46 Profantová 2005, 73, Fig. 9.

47 Profantová 2005, 69, Fig. 5; 74, Fig. 10.

48 KUZMA-ŠALKOVSKÝ 1985, 138.

9 RejHOlCovÁ 1988, 438.

50 ČAPLOVIČ 1954, 12 ff, 16, 18 ff, 22.
}

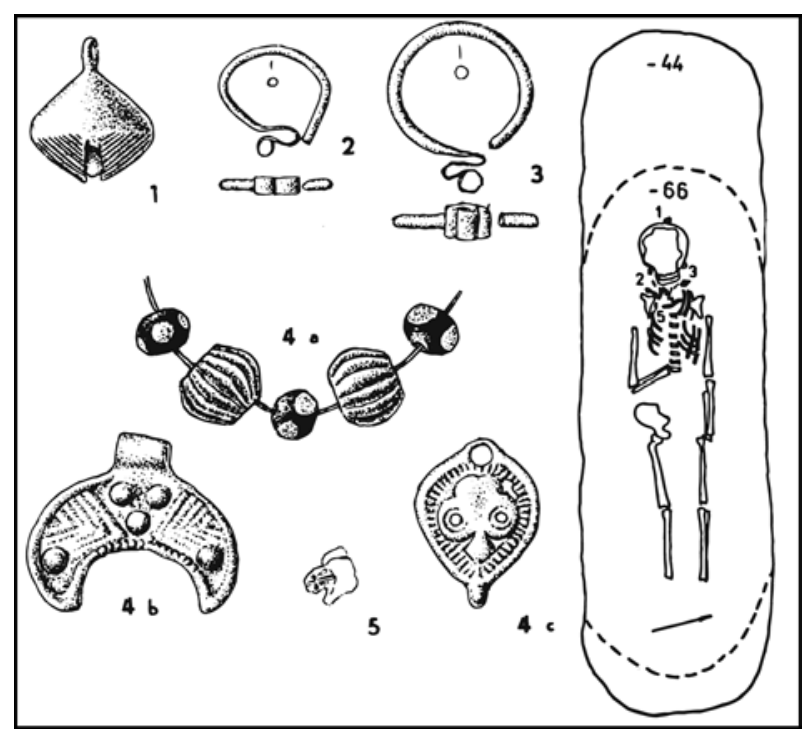

Fig. 12. Malé Kosihy. Pompously equipped child grave no. 147 (after HANULIAK 1994, 124, 173, modified)

12. kép. Kiskeszi/Malé Kosihy. 147. sír. Gazdag mellékletú gyermek (HANULIAK 1994, 124, 173 nyomán, módosítva)

nice. ${ }^{51}$ Out of the total of 143 children's graves up to 5 of them, of the infans II age group, from graves nos. 98, 147, 231, 261 and 403, can be considered very rich in inventory. ${ }^{52}$

From an even earlier phase of the burial site, dated back to the end of the $9^{\text {th }}$ century and the beginning of the $10^{\text {th }}$ century, comes a palatial child grave no. 261. It included a silver earring, three silver-plated bronze fittings with leaf ornaments, overall 27 silver-plated bronze armorial-shaped fittings, a button, a silver-plated bronze buckle, a tongue-shaped strap end and two arrowheads (Fig. 11). ${ }^{53}$ The pompously equipped child grave no. 147 contained a child buried with a bronze sleigh bell, a silver and a bronze s-shaped temple ring, a necklace consisting of five beads, a bronze crescent pendant and a silver embossed two-part heart-shaped pendant. A silver Belo Dux coin was found in this grave as well, dating the grave unit back to mid- $11^{\text {th }}$ century (Fig. 12). ${ }^{54}$

\section{From the $11^{\text {th }}$ century onwards}

In terms of burial rite from the Árpád dynasty period, we can observe simplification of its specific elements. The features that used to be one of the standards of elite graves have been eliminat-

51 HANULIAK 1994

52 HANULIAK 1994, 121, 124, 128-129, 134-136.

53 HaNUliaK 1994, 129, 192.

54 HANULIAK 1994, 124, 173. 
ed. Use of wood for modification of the burial pit is on retreat, grave goods are reduced. These changes can be attributed to the ever growing influence of Christianity. ${ }^{55}$ In spite of the poor occurrence of such richly equipped graves, there are a few isolated cases of children's graves with such burial rite that explicitly vouches for interest, relation and specific rank within the then community. ${ }^{56}$

The most remarkable of them is the grave no. 78/06 located on a churchyard cemetery in Kostol'any pod Tribečom. ${ }^{57}$ The grave of a girl (infans II), ${ }^{58}$ situated near the Church of St George, held the richest grave goods of all researched graves on the cemetery and at the same time it was one of the richest graves in terms of grave goods in all churchyard burial grounds in Slovakia. As parts of the afterlife inventory, jewellery and a coin were found in the grave. ${ }^{59}$ One particular piece of jewellery deserving of special attention was a necklace consisting of 36 beads of various materials. ${ }^{60}$ Other pieces of jewellery were a silver bezel ring and two s-shaped temple rings. Another find from this grave was a coin - a denarius of Oldřich I - which served as Charon's obol..$^{61}$ The discovery of this coin helped estimate the age of the grave as well as the date of the construction of the brick church. ${ }^{62}$

A similar sight can be seen on a cemetery near a gothic-style cathedral in Martin, where a grave of a girl is located. The grave goods include a unique ring with an engraved stylized lily and a heart, as well as 95 beads (glass, pastose, semi-precious stones), placed around the girl's skull. ${ }^{63}$

\section{Conclusion}

From the aforementioned theses we can assume that various early medieval communities on the territory of Central Europe put some great effort to show the importance of child individuals of higher social class and by that demonstrate their particular place in the then communities regardless of age or gender. In terms of archaeological material, it is shown to a large extent by analogical phenomena that can be observed in adult elite individuals buried on inhumation burial sites

\footnotetext{
55 RejHolcová 1995, 88.

5 MolnárovÁ-Borzová 2016.

BAXA-BISTÁK 2009.

KolEnA-LUPTÁKOVÁ 2009.

BAXA et al. 2006, 261.

STAŠŠÍKOVÁ-ŠTUKOVSKÁ-HLOŽEK 2009

HUNKA 2009.

62 BAXA-BISTÁK 2009.

3 BUDINSKÝ-KRIČKA 1944, 5-50.
}

and cemeteries dating from the mid-7th to mid$11^{\text {th }}$ century. Those primarily include sumptuous grave goods, special modification of the burial pit, extraordinary placement of the graves within the burial ground, as well as joint burial including an adult elite individual.

Within the shorter periods of the Early Middle Ages, we can observe a certain deviation of the assessed phenomenon under the influence of distinct social and ethnic-cultural development.

Based on analysis of children's inhumation graves from the period of the Avar Khaganate, we can promptly single out several elite children's groups. First of all there is a very specific group of the so-called children 'cavalry'. The typical feature of this group, similar to adult horsemen, is joint burial together with a horse in an opulent harness, rich grave goods demonstrating the attributes of a horseman (parts of a belt and weapons), as well as special modification of the burial pit. The existence of the children 'cavalry' at the age of 1-3 years underlines the assumption of an exclusively symbolic role of grave goods and elements. Aside from these, there are children's graves from cemeteries of this period, where the horse is absent; however, the grave goods are extremely rich. In case of boys' graves, the attributes are of a warrior - usually weapons and belt parts; girls' graves, on the other hand, contain various kinds of jewellery. Sporadically, we can come across graves of children that were sent to the other side with both male and female attributes, which again underlines the symbolic function of the grave goods. The function of grave goods was to demonstrate the significance of the child in society. In addition to rich grave goods, another very common feature was specific modification of the burial pit, either performed with timber or stone. Such modification further emphasizes the exceptionality of the given burial units.

The following period (mid-9 th to early $10^{\text {th }}$ century) is characterized by distinctive political, governmental, social as well as religious changes. In contrast to the previous period, the symbol of a horseman-warrior is in terms of the burial rite 'only' expressed by means of equipment parts (primarily spurs), weapons and belt sets. Despite the fact that the evaluated unit does not include a large amount of such children's graves, the few instances give evidence of a specific status of such child individuals in the Great Moravian communities. Necropolises of that period hold children's graves with other attributes that account for high social status - flamboyant jewellery. In addition to grave goods, Great Moravian communities tried to express their so- 
cial status by other means that can be observed in the burial rite. It is special modification of the burial pit using wood or stone, as well as location of the grave within the area of the burial site. A new element in the burial rite, in comparison to the period of the Avar Khaganate, is the existence of burials located close to churches as a demonstration of high social rank. In spite of no evidence of such graves on our territory, the Central European territory holds accounts of richly equipped children's burials that are located either very close to a church or, in some instances, directly within the interior of a church.

Regarding the burial rite, even after the arrival of the Magyars to the Carpathian Basin, children's graves characterized by extraordinary inventory continue to appear. Their exceptionality is distinctly marked by jewellery or pompous parts of clothing such as buttons. In rare cases we can find rattles as well. Except for this particular symbol, there are no other manifestations expressing a different, or to be precise, extraordi- nary social status of an individual in terms of burial rite.

In the Árpád dynasty period, because of the growing influence of Christianity, it is possible to record the observed phenomenon only sporadically. It is a combination of two elements that show higher status of children in this period. The first element is represented by specific grave goods, especially jewellery in children's graves; the second one is expressed by an exceptional location of the grave within the burial site - close to a sacred building.

In terms of the burial rite of children's graves, the aforementioned manifestations do not only indicate social status of the youngest members of society of that period; they present perception, attitude and relation of the communities towards children. In a broad sense, they simultaneously inform us about the spiritual world and the conceptions of humans in the observed period that in many respects would be met with restricted understanding by present-day people.

\section{REFERENCES}

BAXA, Peter-Bisták, Peter

2009 Prvé výsledky revízneho archeologického výskumu cintorína pri Kostole sv. Juraja v Kostol’anoch pod Tribečom. Monumentorum tutela. Ochrana pamiatok (Bratislava-Praha) 21, 53-64.

Baxa, Peter-Polanský, Luboš-Bisták, Peter

2006 Příspěvek k česko-uherským kontaktům na přelomu 10. a 11. století. Hrobový nález denáru Oldřicha I. (1012-1033, 1034) v Kostol'anoch pod Tribečom. Numismatický sborník (Praha) 26, 260-265.

BeŇUš, Radoslav-Masnicová, SoŇA-Thurzo, Milan-Katina, StanislaV

2006 Paleopatologické lézie u nedospelých jedincov zo slovansko-avarského pohrebiska Cífer-Pác. Slovenská antropológia: bulletin Slovenskej antropologickej spoločnosti pri SAV (Bratislava) 9:1, 1-3.

BeŇUŠ, RadoslaV-Masnicová, SOŇA-THURZO, Milan

2006 Paleopatologické lézie u nedospelých jedincov z dvoch stredovekých populácií v Devíne. Slovenská antropológia: bulletin Slovenskej antropologickej spoločnosti pri SAV (Bratislava) 9:1, 1-5.

Beňuš, Radoslav-Masnicová, SoŇa-Thurzo, Milan-Panenková, Petra

2007 Paleopatologické lézie u nedospelých jedincov kostrového súboru z Dómu sv. Martina v Bratislave. Slovenská antropológia: bulletin Slovenskej antropologickej spoločnosti pri SAV (Bratislava) 10, 1-3.

BEŇUŠ, RAdOSLAV-OberTovÁ, ZuZANA-MASNiCOVÁ, SOŇA

2010 Demographic, Temporal and Environmental Effects on the Frequency of cribra orbitalia in Three Early Medieval Populations from Western Slovakia. HOMO - Journal of Comparative Human Biology 61, 178-190.

BIALEKOVÁ, DARINA

1993 Slovanské pohrebisko v Bojničkách. Študijné zvesti Archeologického ústavu Slovenskej akadémie vied (Nitra) 29, 223-258.

BRATHER, SEBASTIAN

2004 Alter und Geschlecht zur Merowingerzeit. SozialeStrukturen und frühmittelalterliche Reihengräberfelder. Universitätsforschungen zur Prähistorischen Archäologie (Kiel) 126, 157-178.

BUDINSKÝ-KRIČKA, VOJTĚCH

1944 Prvé staroslovenské radové pohrebištia v Turci a v Liptove: Prvé nálezy staroslovenských radových pohrebíšt' hradištných na Strednom Slovensku. Martin.

1959 Slovanské mohyly v Skalici: Slawische Hügelgräber in Skalica. Bratislava.

BUDINSKÝ-KRIČKA, VOJTĚCH-TOČíK, ANTON

1991 Šebastovce. Gräberfeld aus der Zeit des awarischen Reiches: Katalog. Nitra. 
CRAWFORD, SALLY

1993 Children, Death and the Afterlife. Anglo-Saxon Studies in Archaeology and History (Oxford) 6, 83-92.

2007 Companions, Co-incidences or Chattels? Children in the Early Anglo-Saxon Multiple Burial Ritual. BAR

ČAPLOVIČ, PAVOL International Series 1696. Studies in Archaeology, History, Literature and Art 1, 83-92.

1954 Slovanské pohrebiště v Nitre pod Zoborom. Slovenská archeológia (Nitra) 2, 6-50.

ČILINSKÁ, ZLATA

1963 Slovansko-avarské pohrebisko v Žitavskej Tôni. Slovenská archeológia (Nitra) 11, 87-120.

1966 Slawisch-awarisches Gräberfeld in Nové Zámky. Bratislava.

1973 Frühmittelalterliches Gräberfeld in Želovce. Bratislava.

1982 Dve pohrebiská z 8.-9. storočia v Komárne. Slovenská archeológia (Nitra) 30, 347-393.

ČILINSKÁ, ZLATA-WOLSKA, WANDA

1979 Štrukturálna a demografická analýza včasnohistorického pohrebiska v Želovciach. Slovenská archeológia (Nitra) 27, 139-164.

DÖRNHÖFEROVÁ, MÁRIA-BEŇUŠ, RADOSLAV

2010 Prevalencia zápalových zmien v prínosových dutinách jedincov včasnostredovekej populácie v Borovciach (okr. Piešt́any). Slovenská antropológia: bulletin Slovenskej antropologickej spoločnosti pri

ĎURICOVÁ, MARTA SAV (Bratislava) 13, 11-15.

2012 Pohrebný rítus na pohrebiskách obdobia avarského kaganátu na Slovensku. Unpublished PhD dissertation. Comenius University in Bratislava.

EISNER, JAN

1952 Devínska Nová Ves. Slovanské pohřebište. Bratislava.

FUSEK, GABRIEL

1994 Slovensko vo včasnoslovanskom období. Nitra.

GALUŠKA, LUDĚK

1996 Uherské Hradiště-Sady. Křest́anské centrum říše velkomoravské. Brno.

HANULIAK, MiLAN

1994 Malé Kosihy I. Pohrebisko z 10.-11. storočia (Archeologicko-historické vyhodnotenie). Nitra.

2004 Vel'komoravské pohrebiská. Pochovávanie v 9.-10. storočí na území Slovenska. Nitra.

2010 Sociálna pozícia detských jedincov petrifikovaná v pohrebiskovom materiáli z 9.-10. storočia. Archaeologia Historica (Brno) 35,169-181.

HUNKA, JÁN

2009 Numizmatický a historický význam mincí objavených pri výskume Kostola sv. Juraja. Monumentorum tutela. Ochrana pamiatok (Bratislava-Praha) 21, 65-71.

JAKAB, JÚLIUS

1993 Antropologische Analyse des Gräberfeldes in Komárno-Schiffswerft II. Slovenská archeológia (Nitra) 41, 309-329.

JAKAB, JÚLIUS-VONDRÁKOVÁ, MÁRIA

1982 Antropológia kostier z 8. storočia z pohrebísk v Komárne. Slovenská archeológia (Nitra) 30, 395-427.

KolENA, BRANISLAV-LUPTÁKOVÁ, LENKA

2009 Antropologická analýza jedinca 78/06. Monumentorum tutela. Ochrana pamiatok (Bratislava-Praha) 21, 91-96.

KuZMA, IVAN-ŠALKOVSKÝ, PeTER

1996 Šiesta sezóna výskumu v Mužle-Čenkove. Archeologické výskumy a nálezy na Slovensku v roku 1985 (Nitra), 136-140.

KRASKOVSKÁ, L'UDMILA

1966 Slovanské pohrebisko v Blatnom. Zborník Slovenského národného múzea. História 6, 95-114.

MOLNÁROVÁ, MARTINA

2015 Deti vo včasnom stredoveku z pohl'adu archeológie. Unpublished Mgr. thesis. Constantine the Philosopher University in Nitra. Nitra.

MolnáRová, MartinA-BORZOVÁ, ZuZANA

2016 Deti v spoločnosti včasného stredoveku v zrkadle archeologických prameňov. Archaeologia Historica (Brno) 41/2, 59-76.

NEVIZÁNSKY, GABRIEL

1980 Záchranný výskum v Kameníne. Archeologické výskumy a nálezy na Slovensku v roku 1978 (Nitra), 187-188.

Plachá, Veronika-HlaVicová, JanA-Keller, Igor

1990 Slovanský Devín. Bratislava.

PROFANTOVÁ, NAĎA

2005 Elita v zrcadle dětských pohřbů 9. a 10. století v Čechách. Slovenskej akadémie vied (Nitra) 37, 63-79. 


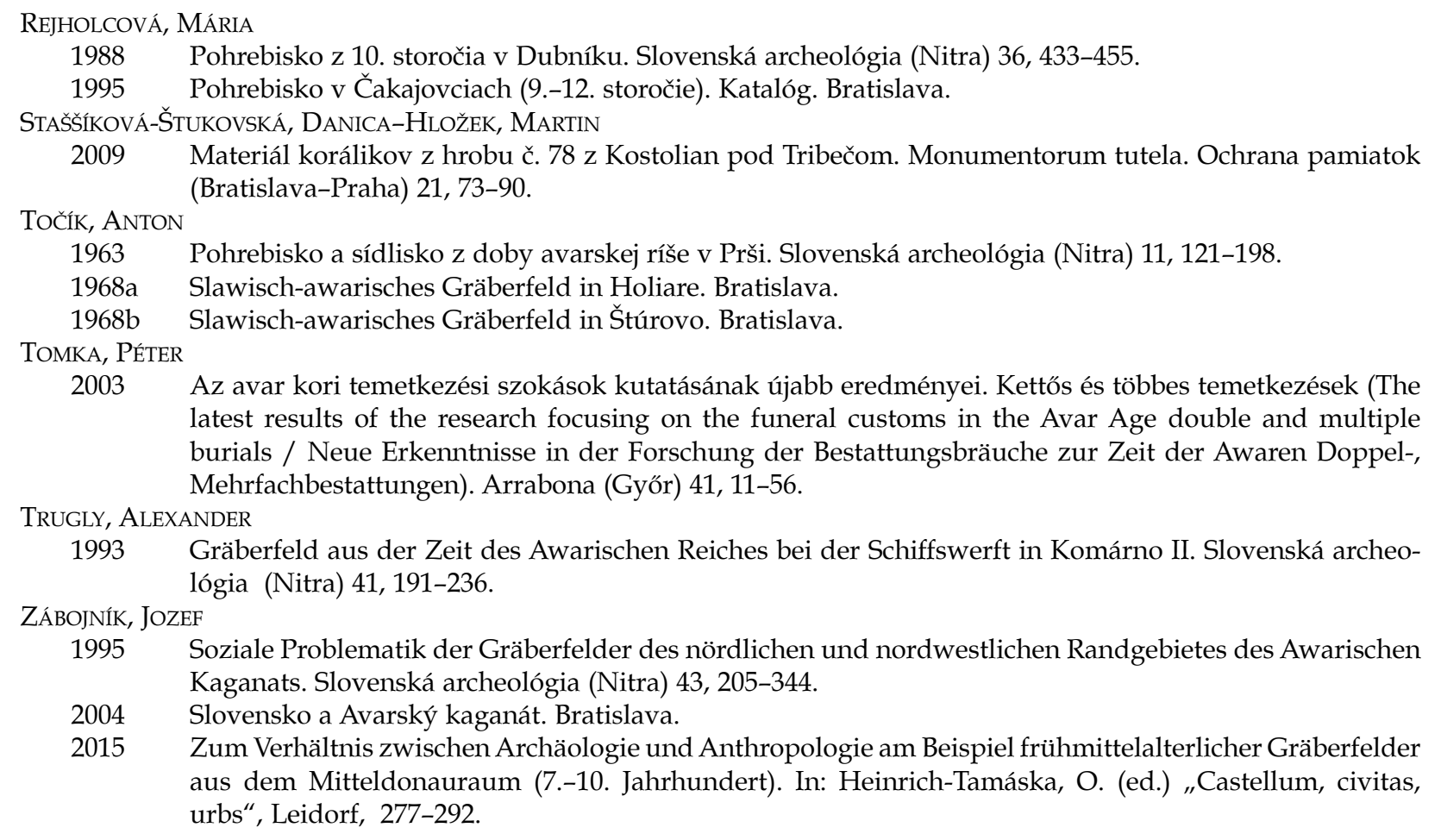

\title{
ELIT GYERMEKEK A KORA KÖZÉPKORBAN
}

\author{
ZuZANA BorZovÁ - Martina MolnáROVÁ
}

A gyermekek és világuk (nem csak) a kora középkorban rendkívül érdekes és mindeddig kevésbé kutatott témakör. Az ezzel összefüggő kérdésekre a régészet elsősorban a 6-12. századi gyermeksírokban találhatja meg a választ. A mai Szlovákia területén eddig 142 kora középkori lelőhelyen 3469 gyermeksírt tártak fel. A tanulmány alapjául "csak” az Infans I és Infans II korcsoportba (0-14 év) tartozó sírok adatbázisa szolgál, ami 134 kora középkori lelőhelyről 2661 gyermeksírt jelent (MoLNÁROVÁ 2015). Néhány esetben a temetkezés jellegzetességei arra utalnak, hogy a gyermek a kora középkori elit réteg tagja volt.

A kora középkor kezdeti szakaszában (5. század vége - 7. század első fele), amikor a szlávok a Kárpátmedencébe érkeztek, majd letelepedtek, a temetkezéseikre a hamvasztásos rítus volt a jellemző. A vizsgált területen az elterjedt temetkezési forma a szegényes mellékletú urnás és szórt hamvas temetkezés, ami nem teszi lehetővé a társadalom tagozódásának, illetve ezen belül a gyermekek helyzetének megfigyelését.

Az Avar Kaganátus időszakában (7. század második fele - 9. század eleje) a mai Nyugat-, Közép- és KeletSzlovákia déli területei az Avar Kaganátus hatalmi-politikai egységének ún. északi perifériáját alkották. Ekkor vált uralkodóvá a csontvázas temetkezés szokása. Az avar kori gyermeksírok elemzése alapján több elit csoport is megkülönböztethető.

A sírok egy nagyon sajátos csoportját alkotják az ún. gyermek „lovasok". A felnőtt lovas temetkezésekhez ha- sonlóan a gazdag melléklettel (öv, fegyverek) ellátott gyermek mellé díszes lószerszámmal felékesített lovat temettek. Erre a csoportra jellemző a sírgödör sajátos kialakítása is. Az a tény, hogy az avar kori temetkezések közt feltúnnek 1-3 év közötti gyermek „lovas” sírok is, megerősíti azt a feltételezést, hogy a sírmelléklet ebben a korban (is) szimbolikus jelentéssel bírt.

A második csoporthoz azok a sírok tartoznak, amelyekben a gyermeket nagyon gazdag melléklettel együtt temették el - fiúk esetében a harcosok attribútumaival (fegyverek, övek), a lányoknál pedig különböző típusú ékszerekkel -, lovat azonban nem helyeztek melléjük. Néhány esetben a sírban nyugvó gyermek mellett megtalálhatók mind a férfi, mind a női attribútumok, ami ugyancsak a melléklet szimbolikus tartalmára utal, és tükrözi a gyermek társadalmi helyzetét. A sírmellékletekkel gazdagon ellátott sírok gödrének kialakítása ebben az esetben is jellegzetes: a sírgödröt kővel vagy fával borították, ez szintén a temetkezés kivételességét fejezi ki.

Az avar kori gyermeksírok következő jelentős csoportját a többes sírok alkotják. Ebben az esetben a gyermeket melléklet nélkül ugyan, de az elit társadalmi réteghez tartozó felnőtt - lovas - mellé temették. Előfordul olyan többes temetkezés is, amikor a gyermeket szintén egy gazdag melléklettel eltemetett felnőtt mellett helyezték nyugalomra, de ló nem volt a sírba helyezve. Többnyire itt is jellemző a sírgödör jellegzetes kialakítása, és ebben az esetben is a felnőtt vázhoz tartoznak a gazdag sírmellékletetek, a gyermeksír pedig melléklet nélküli. Az említett 
temetkezési módnak, azaz a gyermek elit felnőtt mellé helyezésének oka ez idáig ismeretlen. Lehetséges, hogy a lovas férfi és a gyermek rokoni kapcsolatban álltak egymással, és ebben az esetben a temetkezési mód a gyermek társadalmi szerepére, illetve az elit réteghez való tartozására utal. A másik lehetséges magyarázat az, hogy a gyermekre fontos „küldetést” bíztak, jelenlétével védenie kellett felnőtt társát, és követnie kellett őt a másvilágra. A gyermeknek így fontos feladatot kellett elvégeznie, ami az ő különlegességére utal. Kérdés, hogy ebben az esetben a gyermek is az elit réteghez tartozott-e.

Az avar kort követő időszakban (9. század közepe 10. század eleje) jelentős hatalmi, politikai, társadalmi és vallási változások mentek végbe a térségben. A temetkezési rítusban lovas harcos jelenlétére - az előző időszakkal ellentétben - már "csak” a lovas felszerelés részei (elsősorban a sarkantyúk), továbbá a fegyverek és az övek utalnak. Bár az adatbázisban csak kisszámú sír tartalmazza az említett mellékletet, ez is elegendő annak bizonyítására, hogy a nagymorva közösségekben egyes gyermekek jelentős társadalmi ranggal rendelkeztek. Az idesorolt lelóhelyeken elófordulnak továbbá olyan sírok is, amelyekben a gyermek magas társadalmi helyzetéról pompás ékszerei tanúskodnak. Az egyén társadalmi rangját ebben a korban a mellékleten kívül más eszközökkel is igyekeztek szemléltetni: idesorolható a sírgödör fával vagy kővel való borítása, illetve a sír temetőn belüli elhelyezése is.

A gyermekek társadalmi állását a nagymorva időszakban a sírok egy olyan jellegzetes csoportja is kifejezi, amelyet gyermekek és felnőttek többes temetkezései alkotnak. Ezekben az esetekben a gyermekek többségét gazdag sírmelléklettel temették el a sírleletei alapján ugyancsak magas rangú felnőtt mellé. Itt a gyermek kiemelkedő társadalmi helyzetét a közösségben egyrészt az elit réteghez tartozó felnőtt jelenléte, másrészt a gyermek saját gazdag sírmelléklete bizonyítja. A kimagasló társadalmi rangot erősíti ebben a csoportban is a gondosan kialakított sírgödör.

Az eltemetettek magas társadalmi helyzetére utalhat az ebben a korban a keresztény térítés hatására megjelenő, az új gyakorlatnak megfelelő temetkezés a keresztény templomok mellett. Közép-Európa más területein van példa olyan temetkezésre, ahol a gyermeket gazdag melléklettel a templom közelében, sőt annak belső terében helyezték nyugalomra, de a jelen tanulmányban vizsgált területen ilyen típusú leletegyüttes még nem került napvilágra.

Az új etnikum, a magyarok Kárpát-medencei letelepedése után továbbra is előfordulnak gazdag gyermeksírok. Egy lelőhelyen belül többnyire csak egy vagy két ilyen jellegú sír található. A gyermekek kiemelkedő társadalmi rangját ezekben az esetekben főként pompás ékszerek és ruhadíszek fejezték ki.

Az Árpád-korban, a 11. századtól kezdődően a kereszténység elterjedése és temetkezési normatíváinak fokozatos elfogadása miatt a sírokból származó régészeti forrásbázis szúkül. Ebben a korban a gyermekek magasabb társadalmi helyzetét két elem kombinációja bizonyíthatja: a sírok mellékletei (főként a nemesfém ékszerek) és a sírok elhelyezkedése a temetőn belül, elsősorban a templomhoz való viszonyuk (közelségük).

A tanulmányban felvázolt elméletek alapján arra lehet következtetni, hogy a kora középkor egyes közép-európai társadalmai igyekeztek hangsúlyozni a felsóbb társadalmi rétegekhez tartozó gyermekek kiemelkedő szerepét, és nemtől és kortól függetlenül így szemléltették a közösségben elfoglalt helyüket. Az anyagi kultúrában ez a jelenség az elit felnőttek csontvázas sírjaihoz hasonló módon mutatkozik meg a 7-11. században: azaz elsősorban a gazdag melléklet, a sírgödör különleges kialakítása, a sír temetőn belüli megkülönböztetett elhelyezkedése, illetve a gyermek és magas rangú felnőtt kettős temetkezése a jellemző.

A gyermekek temetkezési rítusának fent említett elemei nemcsak az előkelő réteg eme legkisebb tagjainak társadalmi helyzetére utalnak, hanem a korabeli közösségnek a gyermekekkel kialakított kapcsolatát, a hozzájuk való viszonyát tükrözik. Tágabb összefüggéseket tekintve ezek a jelenségek információkkal szolgálnak a vizsgált kor embereinek belső világáról és képzeteiről, amelyeket a mai ember már csak korlátozottabb mértékben képes értelmezni. 